\title{
Analysis of the Challenges and Countermeasures of College English Education in Media and Information Era
}

\author{
Huang Hong \\ Jiangxi Police Institute; \\ Nanchang, China 330100
}

\begin{abstract}
In the current media and information age, the communication mode of information has changed greatly. College English teaching also faces the change of teaching environment. So, education has many challenges. College English is different from other courses, and the learning of many English contents needs to be combined with practice. In the media era, English teaching should be reformed according to certain principles and corresponding measures should be taken to ensure the te aching effect.
\end{abstract}

Keywords-media information; College English; Challenge countermeasures; The English teaching

Language is a tool for communication. The teaching process of English is a process of language communication. However, in the current media and information age, college English education is facing many challenges. As the teaching method does not combine with the development of The Times, it is difficult to improve students' comprehensive English ability. The teaching effect is affected. The ability of students to communicate in English is even more difficult to guarantee. [1] In the current media and information age, the way of information transmission has changed greatly. The original teaching method is difficult to adapt to the development of The Times. In English teaching, it is necessary to change the original teaching methods according to the characteristics of the media and information age. We should use the teaching reform to improve the overall effect of teaching, which is conducive to the improvement of students' comprehensive quality. [2]

\section{CHANGES OF EDUCATION ENVIRONMENT IN THE AGE OF MEDIA AND INFORMATION}

At present, due to the progress of information technology, new media has achieved rapid development. The development of new media has changed the public access to information. And the change has affected teaching. The way teachers and students get information has also changed a lot. The way information permeates the public has changed. The public's access to knowledge will also be influenced by new media. New media is the product of the development of network information technology. In the new media era, the content of knowledge dissemination can be more abundant. Multimedia technology communication has more content. Knowledge can be learned through the Internet. It can also be seen from the form of knowledge dissemination that new learning methods were born. Traditional knowledge explanation takes the form of face to face, while knowledge dissemination in the new media era will be realized through text, animation, video and other ways. With the development of digital media in particular, knowledge has a new mode of communication [3]. The dissemination of knowledge in the media information age has the characteristics of openness. This expands the scope of education. Education adopts the new media technology design to facilitate the sharing of teaching content and enhance the effect of communication. Because of the limitations of traditional education carriers, the dissemination of knowledge needs to be completed by virtue of a physical place. The dissemination of knowledge and sharing of content will also have certain limitations. In the age of media and information, knowledge dissemination can radiate to a larger scope. This has promoted the development of the education industry, so the teaching should also adapt to the characteristics of media information to carry out the teaching reform. [4]

\section{CuRRENT CHALLENGES OF COLLEGE ENGLISH EDUCATION}

\section{A. English education is not combined with students' majors}

The study of English is closely related to reality, but the current content of English education is not combined with the major of college students. Students have a low level of English application. The application of language includes the ability of listening, speaking, reading and writing. These are also the key points of English education. There are many kinds of majors in university, and English has to play different roles in different professional fields. [5] For example, engineering students need to master reading in English, while foreign trade students need skills in listening and speaking in English. However, the current textbooks used in English have some defects. There is a lack of professional content in the textbooks. We also did not combine the characteristics of each major in the teaching process. Therefore, although the students have passed the cet- 4 and cet- 6 exams, in the practical application, the students' English level are relatively low, and the teaching effect has certain limitations.

\section{B. Students do not pay attention to English learning}

Students' initiative in learning English is related to learning motivation. Students' learning behavior will be affected by learning motivation. Students' language learning can reflect 
their learning motivation. Without learning motivation, learning is difficult to give play to subjective initiative. Students lack initiative in learning English in college. Therefore, they lack initiative in learning English. For many college students who do not major in English, learning English is to cope with cet- 4 and cet- 6 . Therefore, they have no excessive pursuit of English learning. [6] in addition, many college students think they have no plans to leave a message abroad, and they don't want to be engaged in a career related to English in the future, so they lack initiative in learning English. Therefore, they not are motivated to communicate actively in the oral class and lack of interest in English, so the teaching effect is difficult to guarantee.

\section{PRINCIPLES OF EDUCATION REFORM IN COLLEGE ENGLISH IN THE ERA OF MEDIA AND INFORMATION}

\section{A. Creation of teaching environment}

Language learning is reflected in communication, so the creation of language environment is particularly critical in English classroom teaching. In the current English classroom teaching, students have fewer opportunities to communicate in English actively. Students lack the enthusiasm to actively participate, so the effect of English teaching is limited. In order to eliminate the disadvantages of current English teaching, teachers should create corresponding communication situations by combining the teaching contents. The creation of communication situation can be helpful for students to master knowledge. Students can understand the key points of English in the communication situation. This can motivate students' participation and improve the English teaching effect. [7]

\section{B. Focus students'attention}

Learning English involves a lot of important points to remember. Students sometimes find it difficult to guarantee the memory effect and are bored with the memory content. This affects learning. Students can't concentrate on their study, which will affect the overall effect of English learning. The adoption of new media in English classroom teaching can mobilize students' enthusiasm for participation. By creating relevant teaching scenes, teachers can effectively mobilize the enthusiasm of students. Students' interest in English learning will be enhanced. Students can pay attention to English learning, so as to ensure their mastery of English knowledge.

\section{Focus on students' participation}

In the teaching process, we only let the students participate in the teaching process as much as possible; can play a certain teaching effect. In traditional English teaching, students often pay more attention to the teaching of knowledge. There are not many education's in students' emotion, which leads to low interest in learning and low participation in class. The application of pedagogy in English teaching should pay attention to the cultivation of students' emotions and change the traditional passive learning mode so that students can learn independently. In English teaching, students are designed with familiar situations to learn relevant English knowledge, so as to stimulate students' interest in learning English and improve the efficiency of classroom learning. [8]

\section{Stimulate students' interest}

Students' interest is the basis to guarantee the classroom teaching atmosphere, and students' interest is also the basis to guarantee the teaching effect. When students participate in situational teaching, they should not only ensure interest, but also guarantee learning effect. Therefore, teachers should pay attention to the novelty of teaching content in the design of teaching content, so as to enhance students' interest in learning English and help students to remember English knowledge. At present, many English teaching methods are dominated by teachers. Students are passive in receiving knowledge and lack of interest, which will affect the teaching effect.

\section{RESPONSE MEASURES OF EDUCATION IN COLLEGE ENGLISH IN THE ERA OF MEDIA AND INFORMATION}

\section{A. Motivate students' learning motivation}

Teacher's teaching process is the concentrated embodiment of teaching thinking and teaching means. All of these are influenced by the teaching philosophy. Different concepts lead to different teaching effects. The teaching idea reflects the teachers' understanding of the subject and the teaching method. The difference in subject recognition will lead to different teaching concepts in teaching. Therefore, teachers will adopt different teaching methods under the influence of different teaching concepts, and there will be different results. Therefore, teachers should play a leading role in eliminating silence and stimulate students' learning motivation. Students with learning motivation can improve their learning enthusiasm and eliminate negative silence. Teachers should make students aware that in the context of China's reform and opening-up, international exchanges will be increasing, and English will play a big role in external exchanges. Students can acquire knowledge and learn advanced technology by mastering necessary English skills. In addition, students with English skills will have a competitive advantage in employment, which is conducive to employment. The teacher wants the silent students to realize the important role of English.

\section{B. To establish motivational teaching evaluation}

The effect of English teaching needs to be encouraged. In order to guarantee the quality of English teaching, classroom teaching also needs to establish practical incentives for students, analyze and judge the teaching process, and scientifically evaluate students' learning results and teachers' teaching ability. The content of evaluation should cover the whole process of teaching, including students' speaking ability. Teachers should encourage students' interest in learning. In psychology, students are passive and silent, but deep in their hearts, they are eager to get teachers' approval. Teachers should give more affirmation and encouragement to students who lack selfconfidence, starting from protecting students' self-esteem and stimulating their learning initiative. Therefore, in English teaching, teachers should encourage as much as possible, listen to students' expressions patiently, be good at discovering students' progress and timely encourage them, so as to improve students' initiative of expression. 


\section{Create a teaching environment conducive to language communication}

As the teaching environment and atmosphere are the foundation to guarantee the teaching effect, English teaching has certain particularity, so it has higher requirements on the teaching environment and atmosphere. Therefore, the particularity of the learning environment also puts forward higher standards for schools and teachers, and the teaching environment and atmosphere will also affect the learning effect of students. Language learning requires a corresponding language environment, and context plays a key role in improving students' oral English. Although many students have mastered many vocabulary and basic grammar, they cannot communicate in English. This phenomenon is mainly related to the English environment. Students do not have a good command of English communication. Therefore, teachers should create language environment for students as much as possible to help them master the skills of using English to communicate.

\section{Help students eliminate psychological barriers}

Students' psychological barriers are related to a variety of reasons. Teachers should help students eliminate their psychological barriers and improve their confidence by eliminating positive silence caused by psychological barriers in oral classes. The teacher's teaching method should consider the student's psychology, pays attention to the analysis student's psychological feeling. Especially for students with poor oral English, teachers should pay attention to giving play to students' main role in classroom teaching, actively communicate with students, improve students' sense of accomplishment, and encourage students to express their personal ideas in English. In addition, many students have the influence of Chinese thinking in their oral expression. Teachers should cultivate the habit of communicating with English thinking, eliminate the interference of the mother tongue, and guide students to establish the thinking of expressing their inner thoughts in English.

\section{E. Innovation of course teaching}

In the traditional teaching mode, students' English thinking ability is limited. In order to improve the teaching effect of oral English, teachers should explore the teaching mode in accordance with the characteristics of students and gradually improve their oral English. The teaching method is teachercentered, with teachers giving lectures and students attending lectures, but it also has many disadvantages. Students and teachers lack opportunities to interact. For example, with the help of innovative teaching methods of multimedia, students can give play to their initiative, and students can experience the fun of oral English learning through active participation, which can promote students to actively communicate in oral English. Teachers can discuss with students based on the topics that students are interested in, which can improve students' enthusiasm for participation. This way can help eliminate students' tension and improve their enthusiasm.

\section{F. Teaching should be completed in accordance with the actual situation as much as possible}

Instances of English teaching materials due to the number of sometimes difficult to meet the requirements of teaching, so teachers in the teaching of teaching should pay attention to collect the actual cases, more particularly influential works in English, and through these works, lets the student in the actual work of learning to the nutrition absorption, helps to cultivate students' innovative thinking. English teaching has a certain particularity, so English teaching should consider the characteristics of English. The teacher's teaching should be comprehensively analyzed in combination with the design ability of students, and various teaching methods can be adopted in teaching, especially in the current new media era, so that students can master the English learning methods under the new media conditions, so as to achieve the teaching objectives of English. In the process of English teaching, teachers should fully motivate students' learning initiative and constantly provide students' application level.

\section{CONCLUSION}

In the era of media information, great changes have taken place in English teaching environment, brings new challenge to traditional English teaching, English teaching should break through the original teaching mode, through incentives, teaching evaluation, teaching environment and so on a variety of measures to the corresponding teaching reform and innovation, to enhance the English teaching's overall effect.

\section{REFERENCE}

[1] Li Minghui. Analysis on the necessity of English teaching reform in the new media era $[\mathrm{J}]$. China master dissertation full-text database, economics and management album, 2016 (10).

[2] Liang Yulin. How to carry out English teaching reform in the new media era [J]. Culture education, 2014 (10).

[3] Ding Yupei, li ling. Discussion on English teaching reform in new media environment $[\mathrm{J}]$. Journal of Chifeng college: natural science edition, 2015 (9).

[4] Zhang Jiang, Zhang Chunyu. Practice of English academic teaching reform in the context of new media $[\mathrm{J}]$. Communication and copyright, 2017 (2).

[5] Li Yubin. Experience and inspiration of English undergraduate education in the media age -- a case study of Austin, university of Texas, USA [J]. Friends of editors, 2016 (3).

[6] Wang Ying. Thoughts on English teaching reform in the new media era [J]. Journalism, 2014 (6).

[7] Xu Jiannan. Innovation of English course theory and practice teaching [J]. Hua Zhang, 2015 (10).

[8] Wang Ziqi. Discussion on the teaching reform of English major in new media era university [J]. Study of art education, 2017 (3). 